vincing. Though Houssay et al. (1967) showed that sympathectomy decreased the expected hyperketonaemia in pancreatectomized animals, and $\beta$-blockers such as propranolol are known to inhibit free fatty acid release (Abramson et al., 1966), others have shown that the ganglion blocker hexamethonium does not prevent the increase of hyperketonaemia or free fatty acids which follow hypoglycaemia (Werk et al., 1961).

Other mechanisms may be important in effecting these responses to hypoglycaemia. Relative insulin deficiency during hypoglycaemia has been suggested (Amatruda et al., 1962 ; Engel and Amatruda, 1963 ; Scow et al., 1964) but disputed by others (Armstrong et al., 1961). Glucagon release also follows hypoglycaemia, but its effect on ketogenesis is not well established (Penhos et al., 1966). Complex explanations may, however, be unnecessary, and decreased utilization of glucose which occurs if the blood glucose falls below the tissue threshold (Butterfield and Holling, 1959) may be solely responsible for this increased ketogenesis (Shreeve, 1963).

Ketonuria may also be misleading because it does not necessarily herald ketoacidosis. Relatively small rises in the blood ketone bodies may be associated with "strong" ketonuria as indicated by the currently used nitroprusside tests (Ketostix or the Acetest tablet), and the blood levels may be well below those which led to ketoacidosis. Huckabee (1961) thought that a total blood organic acid concentration of $5 \mathrm{mM}$ or more is required in order to alter the acid-base values, and it is clear from Fig. 2 and other work (Watkins and FitzGerald, 1968) that the ketonaemia may be very much less than this when "strong" ketonuria is present. Correct assessment of the significance of ketonuria can therefore be made only by determination of the blood ketone bodies. A semiquantitative estimation of plasma acetoacetate by use of Ketostix is adequate for this purpose (Watkins and FitzGerald, 1968), though more accurate automated determinations are now simple to perform (Salway, 1969).

The work was supported by grants from the Endowment Fund of the United Birmingham Hospitals and the British Diabetic Association. We are grateful for the help of Dr. R. Gaddie with biochemical aspects of the work and to Miss Maureen Betts for technical assistance.
REFERENCES

Abramson, E. A., Arky, R. A., and Woeber, K. A. (1966). Lancet, 2, 1386.

Akerblom, H. (1965). Annales Paediatriae Fenniae, 11, Suppl. No. 25,

Amatruda, T. T., Chase, J. W., and Engel, F. L. (1962). Fournal of Clinical Investigation, 41,738 .

Armstrong, D. T., et al. (1961). American fournal of Physiology, 201, 535.

Burn, J. H., and Ling, H. W. (1928). Fournal of Physiology, 65, 191.

Butterfield, W. J. H., and Holling, H. E. (1959). Clinical Science, 18 147.

Chester, E. M., Travis, R. H., and Mackenzie, M. S. (1966). Diabetes, 15, 307.

Collip, J. B. (1923). Fournal of Biological Chemistry, 55, xxxviii.

Engel, F. L., and Amatruda, T. T. (1963). Annals of the New York Academy of Sciences, 104, 753 .

Gibbard, S., and Watkins, P. J. (1968). Clinica Chimica Acta, 19, 511.

Goodman, J. I. (1955). American fournal of Medicine, 18, 448.

Harrop, G. A. (1927). Archives of Internal Medicine, 40, 216.

Henderson, M. J., Karger, B. A., and Wrenshall, G. A. (1952). Diabetes, $1,188$.

Hinkle, L. E., Conger, G. B., and Wolf, S. (1950). Fournal of Clinical Investigation, 29, 754.

Houssay, B. A., et al. (1967). Diabetes, 16, 259.

Hsia, D. Y. (1964). In Diseases of Metabolism, 5th ed., edited by G. G. Duncan, p. 368. Philadelphia, Saunders.

Huckabee, W. E. (1961). American fournal of Medicine, 30, 833.

Huckabee, W. E. (1961). American fournal of Medicine, 30, 833. The

Treatment of Diabetes Mellitus, 10th ed. London, Kimpton.

Krainick, H. G., and Müller, F. (1938). Klinische Wochenschrift, 17,

McPherson, H. T., Werk, E. E., Myers, J. D., and Engel, F. L. (1958). fournal of Clinical Investigation, 37, 1379 .

Maddock, S. J., and Trimble, H. C. (1928). foumal of the American Medical Association, 91, 616.

Penhos, J. C., Wu, C. H., Daunas, J., Reitman, M., and Levine, R. (1966). Diabetes, 15, 740.

Perkoff, G. T., and Tyler, F. H. (1954). Metabolism, 3, 110.

Poulsen, J. E. (1941). Studies on the Ketosis in Diabetes Mellitus. Copenhagen, Busck.

Salway, J. G. (1969). Clinica Chimica Acta, 25, 109.

Scow, R. O., Chernick, S. S., and Brinley, M. S. (1964). American fournal of Physiology, 206, 796.

Shreeve, W. W. (1963). Annals of the New varb Arademy of Sciences, 104, 772 .

Somogyi, M. (1940). Proceedings of the Soctety of Experimenial Biology and Medicine, 45, 644.

Somogyi, M. (1941). fournal of Biological Chemistry, 141, 219.

Somogyi, M. (1959). American Fournal of Medicine, 26, 169

Stephenson, J. B. P., and Hainsworth, I. R. (1966). Proceedings of the Association of Clinical Biochemists, 5,80 .

Tassopoulos, C. N., Barnett, D., and Fraser, T. R. (1969). Lancet, 1, 1282.

Watkins, P. J., and FitzGerald, M. G. (1968). Diabetes, 17, 398.

Werk, E. E., Garber, S., and Sholiton, L. J. (1961). Metabolism, 10, 115.

Werk, E. E., jun., and Knowles, H. C., jun. (1961). Diabetes, 10, 22.

Williamson, D. H., Mellanby, J., and Krebs, H. A. (1962). Biochemical Fournal, 82, 90 .

\title{
Blood Pressure in a Scottish Island Community
}

\author{
V. M. HAWTHORNE,* M.D. ; C. R. GILLIS, † M.B., CH.B.; A. R. LORIMER, $\ddagger$ M.B., M.R.C.P.GLASG. \\ F. R. CALVERT, $§$ M.B., CH.B., D.P.H. ; T. J. WALKER $\|$
}

British Medical fournal, 1969, 4, 651-654

\begin{abstract}
Summary : A survey of mean blood pressure levels in age-and-sex-matched samples of the population of the island of Tiree appears to support the local belief that blood pressure is higher on the island than on the mainland. This conclusion may be related to the observation of a greater mean width of the heart, measured radiologically, in the island population compared with the mainland population. The greater mean body weight observed in the island compared with the mainland may be a factor. Blood pressure in men between the ages of 40 and 59 years is higher in Tiree than in selected samples in England and America.
\end{abstract}

\section{Introduction}

Cardiovascular disease is the main cause of death in Scotland (Registrar General for Scotland, 1968). Since hypertension may be an important factor in determining risk (Epstein, 1965), a study of the prevalence of hypertension in the popu-

* Senior Lecturer in Epidemiology and Preventive Medicine, University of Glasgow.

† Lecturer in Epidemiology and Preventive Medicine, University of Glasgow.

$\ddagger$ Lecturer in Medical Cardiology, University of Glasgow.

5 General Practitioner, Island of Tiree.

II Science Student, University of Glasgow. 
lation is of interest. Bonar (1965) drew attention to the possibility of a high prevalence of raised blood pressure in his practice on the Hebridean island of Tiree, Argyllshire. As the Glasgow Mass Miniature Radiography Cardiorespiratory Screening Unit offered facilities for multiphasic screening, a study using standardized methods was designed to determine the distribution of blood pressure levels on Tiree and to compare results with those of samples drawn from mainland urban and rural groups in Glasgow and Clackmannan.

\section{Material and Methods}

The island sample was drawn from the Register of Electors (Wilson, 1964) and revised to include all changes up to one month before the survey. The sample comprised 324 male and 351 female istand residents over the age of 15 years-a total of 675 potential examinees.

As it was not possible to obtain a mainland sample of the general population it was decided to use numerically similar age-and-sex-matched groups living in the rural surroundings of Clackmannan and the urban surroundings of Glasgow. These groups comprised individuals working in industry next due to be examined routinely by the cardiorespiratory screening unit.

Each household on the island was visited by a member of the survey team two weeks after a questionary (Rose and Blackburn, 1968) had been delivered by post.

The subsequent examination of the individual at the unit lasted 15 minutes. The self-completed questionary was checked and any doubt about self-estimated height and weight resolved. Thereafter the individual was examined by means of a postero-anterior and left lateral $70-\mathrm{mm}$. chest radiograph, a six-lead seated electrocardiogram (leads I, II, III, AVR, AVL, and AVF), a standing respiratory function test with the Garthur Vitalograph, a triceps skin-fold thickness estimation measured by the Harpenden calliper, and a Labstix analysis of a casual specimen of urine.

A seated blood pressure estimation was made by one of three similarly trained observers. An accurate sphygmomanometer with a cuff 12 by $24 \mathrm{~cm}$. was used, the disappearance of the sounds being recorded as the diastolic pressure. The blood pressure measurements of the three observers had already been compared in a trial employing a cross-over design (Cochran and Cox, 1960). This showed that there were no significant differences between these observers for both systolic and diastolic blood pressure.

The width of the radiological image of the heart was measured by a line connecting the right and left borders of the heart at the points of maximum curvature (Fig. 1).

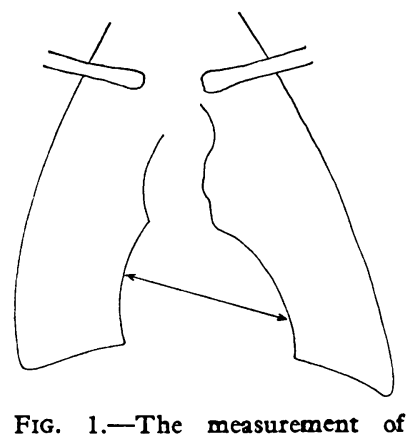

FIG. 1.-The measurem

\section{Results}

Fig. 2 illustrates the response by area of survey. A rate of $80 \%$ was recorded in the island sample compared with $62 \%$ in the rural and $80 \%$ in the urban samples of the mainland population. The estimates of response in the mainland samples were based on the number of employees whose names appeared on the payroll of the industrial organizations on the week of the survey.

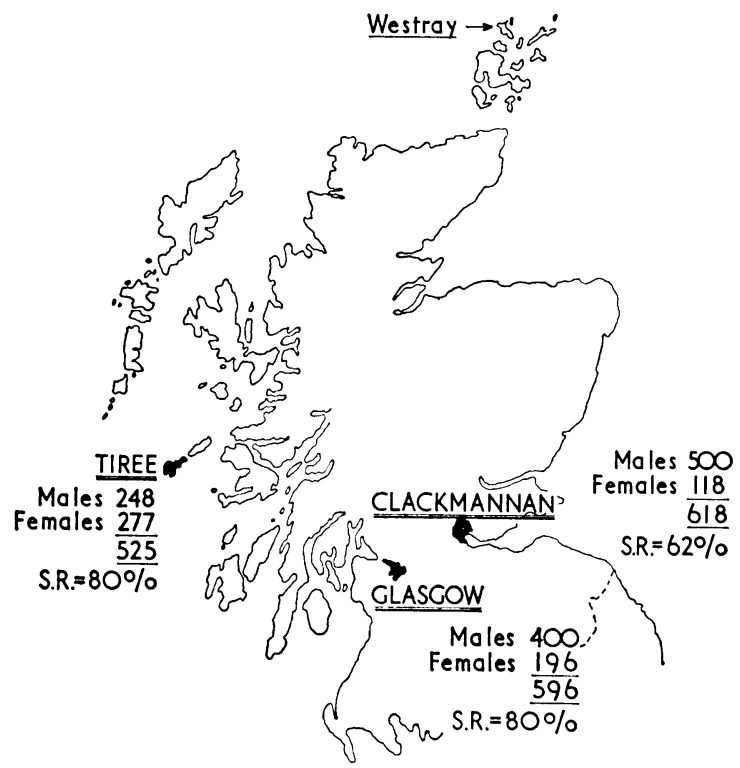

FIG. 2.-The response by area.

Table I shows the number examined in the three samples by age and sex. Numbers were adequate for comparison up to the ages of 64 in males and 59 in females. Thereafter few subjects were available in the mainland samples because of retirement.

TABle I.-Numbers Examined by Age, Sex, and Area

\begin{tabular}{|c|c|c|c|c|c|c|}
\hline \multirow{2}{*}{ Age } & \multicolumn{2}{|c|}{ Tiree } & \multicolumn{2}{|c|}{ Clackmannan } & \multicolumn{2}{|c|}{ Glasgow } \\
\hline & Males & Females & Males & Females & Males & Females \\
\hline $\begin{array}{c}15-19 \\
20-29 \\
30-39 \\
40-49 \\
50-59 \\
60-64 \\
65+\end{array}$ & $\begin{array}{l}14 \\
27 \\
43 \\
59 \\
36 \\
19 \\
50\end{array}$ & $\begin{array}{l}19 \\
16 \\
52 \\
53 \\
41 \\
19 \\
77\end{array}$ & $\begin{array}{r}14 \\
52 \\
64 \\
114 \\
182 \\
62 \\
12 \\
\end{array}$ & $\begin{array}{r}20 \\
35 \\
20 \\
25 \\
14 \\
4 \\
\end{array}$ & $\begin{array}{r}32 \\
69 \\
92 \\
99 \\
75 \\
30 \\
3\end{array}$ & $\begin{array}{r}29 \\
47 \\
41 \\
45 \\
32 \\
1 \\
1 \\
\end{array}$ \\
\hline $15-64$ & 198 & 200 & 488 & 118 & 397 & 195 \\
\hline
\end{tabular}

Fig. 3 shows the means and standard deviations of systolic and diastolic blood pressure by age and sex in the three samples. In each of the age groups where numbers were sufficient for comparison the levels of the Tiree population exceeded those of the mainland. There were few significant differences in blood pressure between Glasgow and Clackmannan, whereas above the age of 30 both systolic and diastolic blood pressures were significantly higher in Tiree than in either Glasgow or Clackmannan.

Fig. 4 and Table II show that the width of the radiological image of the heart was significantly greater in the island than on the mainland.

Table III compares mean systolic and diastolic blood pressure in men aged 40 to 59 . The Tiree sample is compared with the two Scottish mainland samples, with the combined English sample of post office workers from London, Norwich, Peterborough, and Gloucester, and with the combined American sample of telephone workers from Westchester (New York), Washington, and Baltimore (Reid, Holland, and Rose, 1967). The levels in Tiree were higher than in the other samples. 
Table II.-Mean, Standard Deviation, and Significance Levels for Cardiac Width (mm.) by Age, Sex, and Area

\begin{tabular}{|c|c|c|c|c|c|c|c|c|c|c|}
\hline \multirow[b]{2}{*}{ Age } & \multicolumn{5}{|c|}{ Males } & \multicolumn{5}{|c|}{ Females } \\
\hline & Glasgow & $\begin{array}{l}\text { P Value } \\
\text { between } \\
\text { G. and T. }\end{array}$ & Tiree & $\begin{array}{l}\text { P Value } \\
\text { between } \\
\text { T. and C. }\end{array}$ & Clackmannan & Glasgow & $\begin{array}{l}\text { P Value } \\
\text { between } \\
\text { G. and T. }\end{array}$ & Tiree & $\begin{array}{l}\text { P Value } \\
\text { between } \\
\text { T. and C. }\end{array}$ & Clackmannan \\
\hline $\begin{array}{c}15-19 \\
20-29 \\
30-39 \\
40-49 \\
50-59 \\
60-64 \\
65+\end{array}$ & $\begin{array}{l}21 \cdot 6 \pm 1 \cdot 9 \\
21 \cdot 6 \pm 2 \cdot 4 \\
22 \cdot 4 \pm 2 \cdot 5 \\
22 \cdot 0 \pm 2 \cdot 0 \\
22 \cdot 5 \pm 2 \cdot 6 \\
22 \cdot 9 \pm 2 \cdot 9 \\
22 \cdot 7 \pm 1 \cdot 5\end{array}$ & $\begin{array}{l}\text { N.S. } \\
0.1 \% \\
0.1 \% \\
0.1 \% \\
0.1 \% \\
5 \% \\
0.1 \%\end{array}$ & $\begin{array}{l}22 \cdot 3 \pm 2 \cdot 1 \\
25 \cdot 2 \pm 2 \cdot 2 \\
25 \cdot 2 \pm 1 \cdot 7 \\
25 \cdot 3 \pm 2 \cdot 5 \\
25 \cdot 0 \pm 2 \cdot 3 \\
24 \cdot 7 \pm 2 \cdot 5 \\
26 \cdot 8 \pm 3 \cdot 1\end{array}$ & $\begin{array}{l}\text { N.S. } \\
0.1 \% \\
0.1 \% \\
0.1 \% \\
0.1 \% \\
5 \% \\
0.1 \%\end{array}$ & $\begin{array}{l}22 \cdot 1 \pm 2 \cdot 1 \\
22 \cdot 7 \pm 2 \cdot 1 \\
23 \cdot 3 \pm 2 \cdot 2 \\
23 \cdot 1 \pm 2 \cdot 1 \\
22 \cdot 9 \pm 2 \cdot 2 \\
23 \cdot 2 \pm 2 \cdot 2 \\
23 \cdot 4 \pm 1 \cdot 6\end{array}$ & $\begin{array}{l}19 \cdot 3 \pm 1 \cdot 8 \\
20 \cdot 8 \pm 2 \cdot 6 \\
21 \cdot 3 \pm 2 \cdot 5 \\
21 \cdot 1 \pm 2 \cdot 0 \\
22 \cdot 1 \pm 2 \cdot 6 \\
21 \cdot 0 \\
22 \cdot 0\end{array}$ & $\begin{array}{l}0.1 \% \\
0.1 \% \\
2 \% \% \\
0 \cdot 1 \% \\
2 \% \\
=\end{array}$ & $\begin{array}{l}21 \cdot 5 \pm 1 \cdot 5 \\
23 \cdot 3 \pm 1 \cdot 5 \\
22 \cdot 6 \pm 1 \cdot 8 \\
22 \cdot 9 \pm 2 \cdot 4 \\
23.5 \pm 2 \cdot 2 \\
24 \cdot 2 \pm 1 \cdot 8 \\
24 \cdot 5 \pm 2 \cdot 3\end{array}$ & $\begin{array}{l}\text { N.S. } \\
0.1 \% \\
0.1 \% \\
1 \% \% \\
2 . S \% \\
2 \%\end{array}$ & $\begin{array}{c}20.9 \pm 2.3 \\
21 \cdot 0 \pm 2.2 \\
19.9 \pm 1.7 \\
21.3 \pm 2.0 \\
22.6 \pm 1.9 \\
21.5 \pm 1.9 \\
\end{array}$ \\
\hline
\end{tabular}
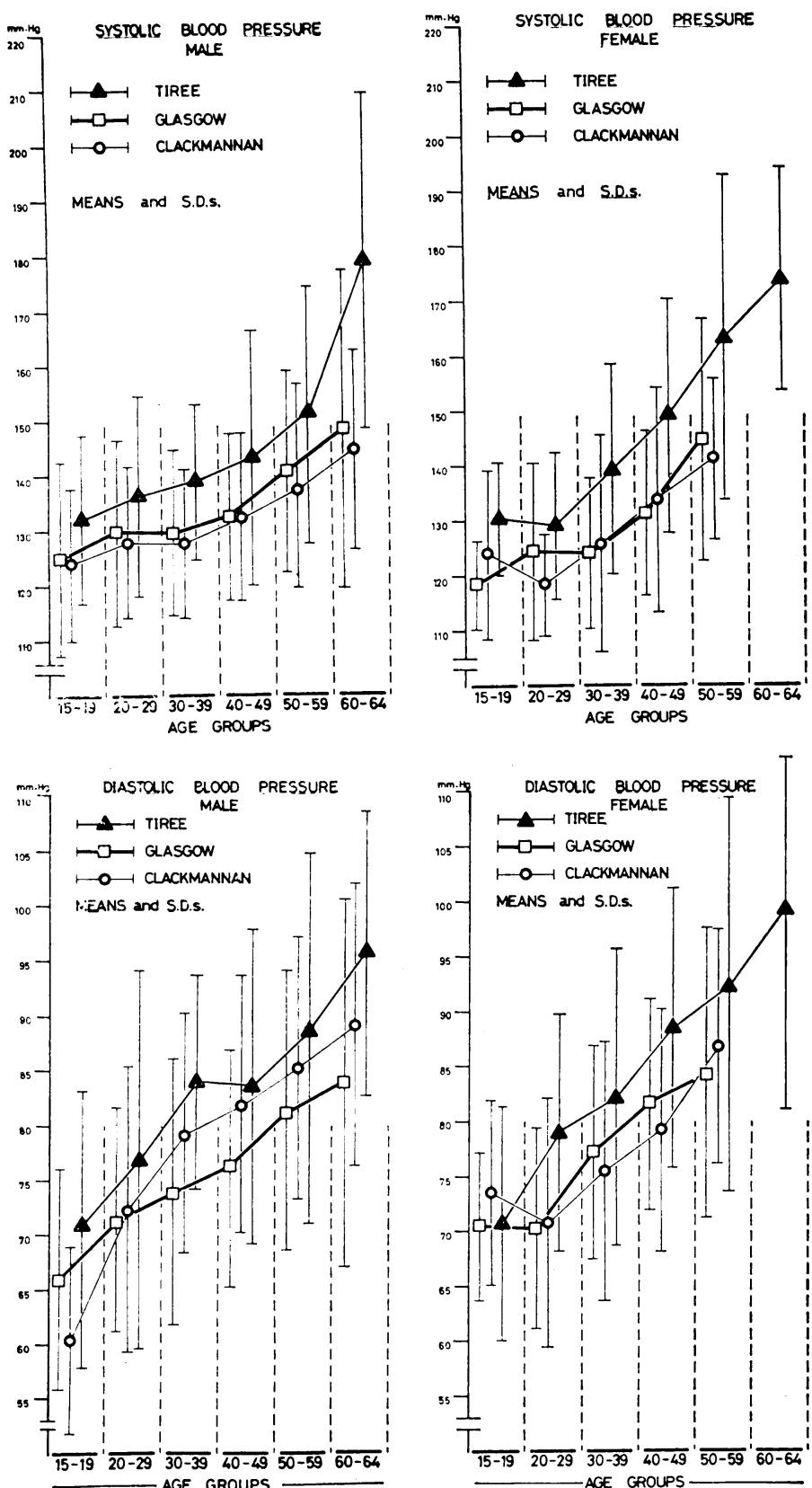

FIG. 3.-The means and standard deviations of systolic and diastolic blood pressure by age and sex in the three samples.
Males and females in Glasgow were shorter than their coevals in Tiree and Clackmannan, between whom differences were not significant. Glasgow males and females were also lighter than their coevals in Tiree, the differences being at a less significant level in females. With the exception of men aged 40 to 59 , the Clackmannan sample had the same relation to the Tiree as the Glasgow sample.

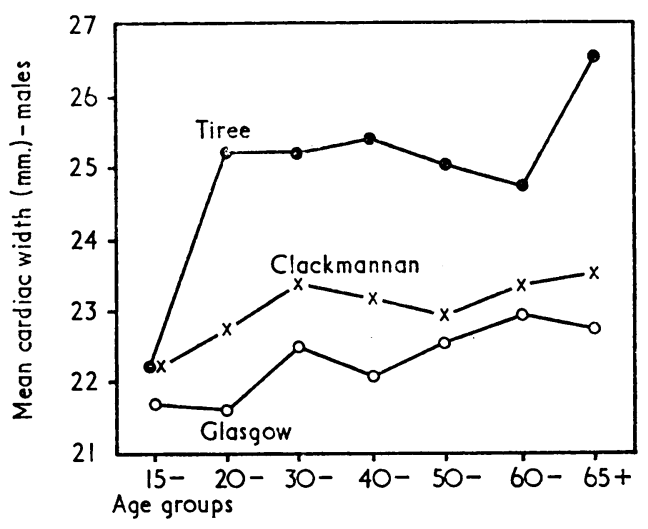

Fig. 4.-The mean cardiac width (mm.) in the three samples for males.

In general there were no apparent differences between the three samples in the proportions showing symptoms of " angina," " infarction," and " intermittent claudication " (Rose and Blackburn, 1968), nor in major and minor E.C.G. evidence of ischaemic heart disease as measured by Minnesota coding summaries I and II (Blackburn, Keys, Simonson, Rautaharju, and Punsar, 1960).

\section{Discussion}

The island of Tiree provides an environment radically different from the urban surroundings of industrial Glasgow and the rural situation of the small towns of Alloa, Tillicoultry, and Menstrie in the County of Clackmannan. Situated 50 sea miles $(92 \mathrm{~km}$.) from the port of Oban and 100 miles (161 km.) from Glasgow Airport, Tiree enjoys a milder climate and a higher rate of sunshine than the mainland (McLaren, 1965). Crofting and cattle-raising provide the main sources of occupation. Despite the progressive attitude of the community and the industry of ito inhabitants, Tiree seems relatively free from the accepted stresses and strains of modern living.

As well as the difficulties associated with comparing a sample drawn from the general population with one drawn

TABLE III.-Blood Pressure (mm. Hg) by Age in Males of the Scottish, English, and American Samples

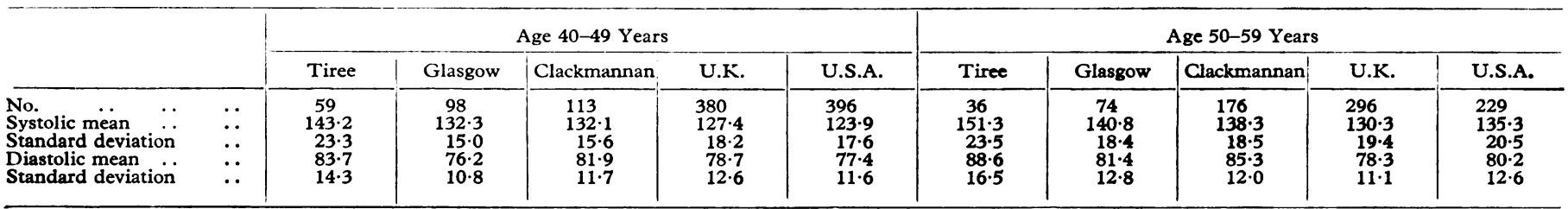


from apparently healthy people at work, the response rate of $62 \%$ in Clackmannan, caused by a strike in one of the factories taking part in the survey, compared rather unfavourably with $80 \%$ in the Glasgow and Tiree samples. On the other hand, the probability that accurate characterization of the Tiree population had been achieved was enhanced by matching the National Health Service records of the Tiree non-respondents with a random selection of the Tiree respondents. This showed that there was less morbidity in the non-respondents than in the respondents.

The survey confirmed the presence of an apparently higher level of blood pressure in age-and-sex-matched samples of the island compared with the mainland. This may be supported by the observation that mean measurements of the transverse width of the radiological image of the heart were significantly larger in the island compared with the mainland samples in all age groups by sex. These observations are associated with several considerations.

For example, arm girth was not measured in these samples. Pickering, Roberts, and Sowry (1954) and Miall and Oldham (1955) thought that the effect of increasing arm girth and body weight was of sufficient importance to require a correction factor. On the other hand, Bøe, Humerfelt, and Wedervang (1957) undertook a large study in Norway, and though they confirmed that obesity and increased arm girth did play a part in raising blood pressure levels they felt that this factor had been overemphasized and that little, if any, correction was required. This view was confirmed by Epstein and Eckoff (1967). W. W. Holland (personal communication, 1969) has now shown that the use of a cuff of standard width is of more importance.

Bays and Scrimshaw (1953) concluded that there was inadequate evidence to suggest that either geographical or cultural factors had a significant effect on the frequency of essential hypertension. More recently, higher mean levels of blood pressure have been reported in American negroes (Comstock, 1957) and higher mean levels of blood pressure in rural as compared with urban populations have been reported in Jamaica (Miall, Kass, Ling, and Stuart, 1962). On the other hand, Lovell (1967) has shown that in certain of the islands of Oceania the blood pressure is lower than expected and does not rise with age. Tiree is an island sample which has higher mean levels of blood pressure than the mainland samples and which also shows an increase with age. The Clackmannan and Glasgow samples are also of interest in that they represent rural and urban communities in which the blood pressure levels are similar.

The mean levels of blood pressure by age and sex were also higher in Tiree than in the selected samples of post office workers in London, Norwich, Gloucester, and Peterborough in the U.K. and their equivalents in Westchester (New York), Washington, and Baltimore in the U.S.A. (Reid et al., 1967). Levels of blood pressure in the Tiree sample also appear to exceed those of the population of the Orcadian island of Westray (W. Taylor, personal communication, 1969).

Significant differences in mortality also postulated by Bonar (1965) in the three samples are unlikely to emerge for several years, but incidence surveys of morbidity planned as part of the longitudinal study may exhibit differences more rapidly than mortality figures.

The greater weight and height of the island samples compared with those of the mainland may prove to have some relevance in explaining the differences in blood pressure, but other possible related factors include diet and water supply, and these are currently being investigated.

The continued surveillance of these samples offers the prospect of investigating further the differences reported in this paper, but larger samples from the Western Isles and mainland samples from the general population may be necessary for conclusive results. The value of multiphasic screening may yet have to be established for the individual, but the procedure is eminently suitable for the study of the natural history of disease in the general population.

The undernoted supplementary tables are available on request direct to us :

Table IVa. Mean and standard deviation for systolic and diastolic blood pressure (mm. $\mathrm{Hg}$ ) in males by area and age.

Table IVb. Means and standard deviation for systolic and diastolic blood pressure $(\mathrm{mm} . \mathrm{Hg})$ in females by area and age.

Table V. $t$-Values and levels of significance for systolic and diastolic blood pressure for males and females between the three samples.

Table VI. Systolic blood pressure by length of stay in Tiree.

Table VIIa. Means and standard deviations for height (in.) and weight (lb.) in males by age and area.

Table VIIb. Means and standard deviations for height (in.) and weight (lb.) in females by age and area.

Table VIIIa. $t$-Values and levels of significance in respect of differences in height in males and females by age in Glasgow and Tiree.

Table VIIIb. $t$-Values and levels of significance in respect of differences in weight in males and females by age in Glasgow and Tiree.

We wish to express our sincere thanks to the people of Tiree, to the members of the Tiree Association resident in the Glasgow area, to the leaders of the community on Tiree, including the Church of Scotland and Baptist ministers, and the employers, employees, and staffs of the industrial medical centres of Samuel Jones, Paton and Baldwin, D.C.L., the Harland Engineering Co., Newalls (G.K.N.), and Cooper, McDougall and Robertson.

We also gratefully acknowledge the assistance of the Department of Epidemiology and Medical Statistics of the London School of Hygiene and Tropical Medicine, the Western Regional Hospital Board, the Board of Management for Glasgow Northern Hospitals, and of Miss E. R. Dalton, of the Department of Epidemiology and Preventive Medicine of the University of Glasgow, who undertook the analyses of the blood pressure observer trial and the effects of length of domicile on blood pressure.

\section{REFERENCES}

Bays, R. P., and Scrimshaw, N. S. (1953). Circulation, 8, 655.

Blackburn, H., Keys, A., Simonson, E., Rautaharju, P., and Punsar, S. (1960). Circulation, 21, 1160.

Bøe, J., Humerfelt, S., and Wedervang, F. (1957). Acta Medica Scandinavica, Suppl. No. 321 .

Bonar, R. B. (1965). Survey of blood pressure among inhabitants of Tiree. (Unpublished communication-author deceased.)

Cochran, W. G., and Cox, Gertrude, M. (1960). Experimental Designs, 2nd ed., p. 127. New York, John Wiley and Sons.

Comstock, G. W. (1957). American fournal of Hygiene, 65, 272.

Epstein, F. H. (1965). Fournal of Chronic Diseases, 18, 735.

Epstein, F. H., and Eckoff, R. D. (1967). In The Epidemiology of Hypertension, edited by J. Stamler, R. Stamler, and T. N. Pullman, p. 155. New York, Grune and Stratton.

Lovell, R. R. H. (1967). In The Epidemiology of Hypertension, edited by J. Stamler, R. Stamler, and T. N. Pullman, p. 122. Grune and Stratton.

McLaren, M. (1965). The Shell Guide to Scotland. London, Ebury Press.

Miall, W. E., Kass, E. H., Ling, J., and Stuart, K. L. (1962). British Medical fournal, 2, 497.

Miall, W. E., and Oldham, P. D. (1955). Clinical Science, 14, 459.

Pickering, G. W., Roberts, J. A. F., and Sowry, G. S. C. (1954). Clinical Science, 13, 267.

Registrar General for Scotland (1968). Annual Report for the Year 1967. London, H.M.S.O.

Reid, D. D., Holland, W. W., and Rose, G. A. (1967). Lancet, 2, 1375.

Rose, G. A., and Blackburn, H. (1968). World Health Organisation Monograph Series, No. 56, p. 172.

Wilson, J. C. (1964). Register of Electors, County of Argyll, Parliamentary Polling District, Scarinish (N-16), County Buildings, Campbeltown. 